\title{
A Low-Profile Subsistence Fishery: Pike Fishing in Minto Flats, Alaska
}

\author{
ELIZABETH F. ANDREWS ${ }^{1}$
}

(Received 31 October 1988; accepted in revised form 4 April 1989)

\begin{abstract}
Subsistence research in contemporary communities in rural Alaska is revealing the important contribution of fish species other than salmon to the food supply, yet the subsistence use of non-salmon species has had a low profile in management and regulatory regimes of the fisheries in Alaska. Management concerns arose when a developing northern pike (Esox lucius) sport fishery occurred in an area with preexisting subsistence uses of pike stocks. The Minto Flats subsistence pike fishery has been part of Minto village's subsistence economy throughout the century, whereas sport fishing for pike in Minto Flats is comparatively recent, coinciding with the growth of the nearby regional center of Fairbanks. The identification of a preexisting subsistence fishery combined with field research to record harvest levels, geographic areas used, and seasonality of harvest contributed to a management plan that enabled conservation and harvest of the resource. Knowledge about the subsistence fishery allowed regulations to be established that provided for compatible uses of the pike fishery by subsistence and sport fishermen by segregating the fisheries in time and place and employing standard management tools.
\end{abstract}

Key words: subsistence fisheries, food fisheries, sport fisheries, northern pike, Esox lucius, fisheries management, Alaska

RÉSUMÉ. La recherche sur la subsistance dans des communautés actuelles des régions rurales de l'Alaska, révèle l'importance de la contribution des espèces de poissons autres que le saumon aux approvisionnements de nourriture. La gestion et les régimes de quotas dans les pêcheries alaskiennes n'ont cependant pas souligné cette utilisation des espèces non salmonidées pour la subsistance. Les préoccupations au sujet de la gestion se sont manifestées au moment où se développait la pêche sportive au grand brochet (Esox lucius) dans une zone où l'on utilisait déjà les réserves de brochets pour la subsistance. La pêche de subsistance au brochet a fait partie de l'économie de subsistance du village de Minto durant tout le siècle, alors qu'en comparaison, la pêche sportive au brochet à Minto Flats est récente et coïncide avec la croissance du centre régional proche de Fairbanks. L'identification d'une pêche de subsistance déjà établie, combinée à la recherche sur le terrain en vue de relever les niveaux d'exploitation, les zones géographiques utilisées et les époques de l'année où a lieu l'exploitation, a contribué à un plan de gestion qui a permis de préserver cette ressource tout en l'exploitant. Le fait que cette pêche de subsistance ait été connue a permis d'établir des règlement qui ont rendu la pêche au brochet possible à la fois comme activité de subsistance et comme activité sportive, en séparant les lieux de pêche dans le temps et l'espace et en utilisant des outils de gestion standards.

Mots clés: pêche de subsistance, pêche reliée à l'alimentation, pêche sportive, grand brochet, Esox lucius, gestion des pêcheries, Alaska

Traduit pour le journal par Nésida Loyer.

\section{INTRODUCTION}

Subsistence uses of fish and game are authorized and protected by the Alaska subsistence law first passed in 1978. This law also established the Division of Subsistence, with a social science research mission. The division's professional staff includes social scientists, biologists, and local subsistence experts. The following is a case example of the kinds of research data collected and the kinds of resource management issues in which the data are applied. It describes the management concerns that arise when a new or developing sport fishery is established in an area and on a stock with preexisting subsistence uses. It shows how compatible uses of a fishery were accommodated consistent with the sustained-yield principle and a subsistence use preference.

Subsistence research in Alaska is revealing the significant contribution of subsistence fish to the food supply of rural Alaska. The role and importance of salmon in the subsistence economies of Alaska has long been noted both in the historic literature and ethnographic studies (Zagoskin, 1967; Allen, 1887; Schwatka, 1893; Osgood, 1940; Wolfe, 1979). The use of non-salmon fish has often been overlooked or reported secondarily, almost as an afterthought; yet this type of fishing has often been of great importance to the rural communities of arctic and subarctic Alaska. Examples of "low-profile" fisheries include northern pike (Esox lucius), whitefish (Coregonus sp. and Prosopium cylindraceum), burbot (Lota lota), sheefish (Stenodus leucichthys), Alaska blackfish
(Dallia pectoralis), Arctic grayling (Thymallus arcticus), and char (Salvelinus alpinus), among others. Even for communities where salmon were harvested nearby, the harvest of these other fish species constituted up to $36 \%$ by weight of the total wild food harvest in certain communities in the 1980s (Andrews, 1988; Marcotte, 1986; Wolfe and Walker, 1987). In addition to the important contribution of these species to the food supply, non-salmon fish species commonly provided a major source of fresh food during transitional times of the seasonal harvest cycle, such as late fall and spring, and throughout winter where people fished through the ice. This relatively long duration of availability has been a special feature of non-salmon fisheries.

One of these low-profile fisheries exists in the community of Minto in interior Alaska. Minto is an Athabaskan Indian community situated $64 \mathrm{~km}$ ( $209 \mathrm{~km}$ by road) northwest of Fairbanks (Fig. 1). In 1987, Minto had a population of approximately 220 people, whereas the Fairbanks North Star Borough in 1985 had a population of 72474 (Alaska Department of Labor, 1987). The Minto Flats subsistence pike fishery has been a part of Minto's subsistence economy throughout this century and earlier. Comparatively, sport fishing for pike in Minto Flats is recent and coincided with the growth of Fairbanks and the Borough. Notable population increases in the Borough from the mid-1970s through the early 1980s and improved road access to Minto Flats, in particular, have contributed to the development and expansion of the Minto Flats sport pike fishery. This paper

\footnotetext{
${ }^{1}$ Division of Subsistence, Alaska Department of Fish and Game, 1300 College Road, Fairbanks, Alaska 99701, U.S.A.

(C) The Arctic Institute of North America
} 


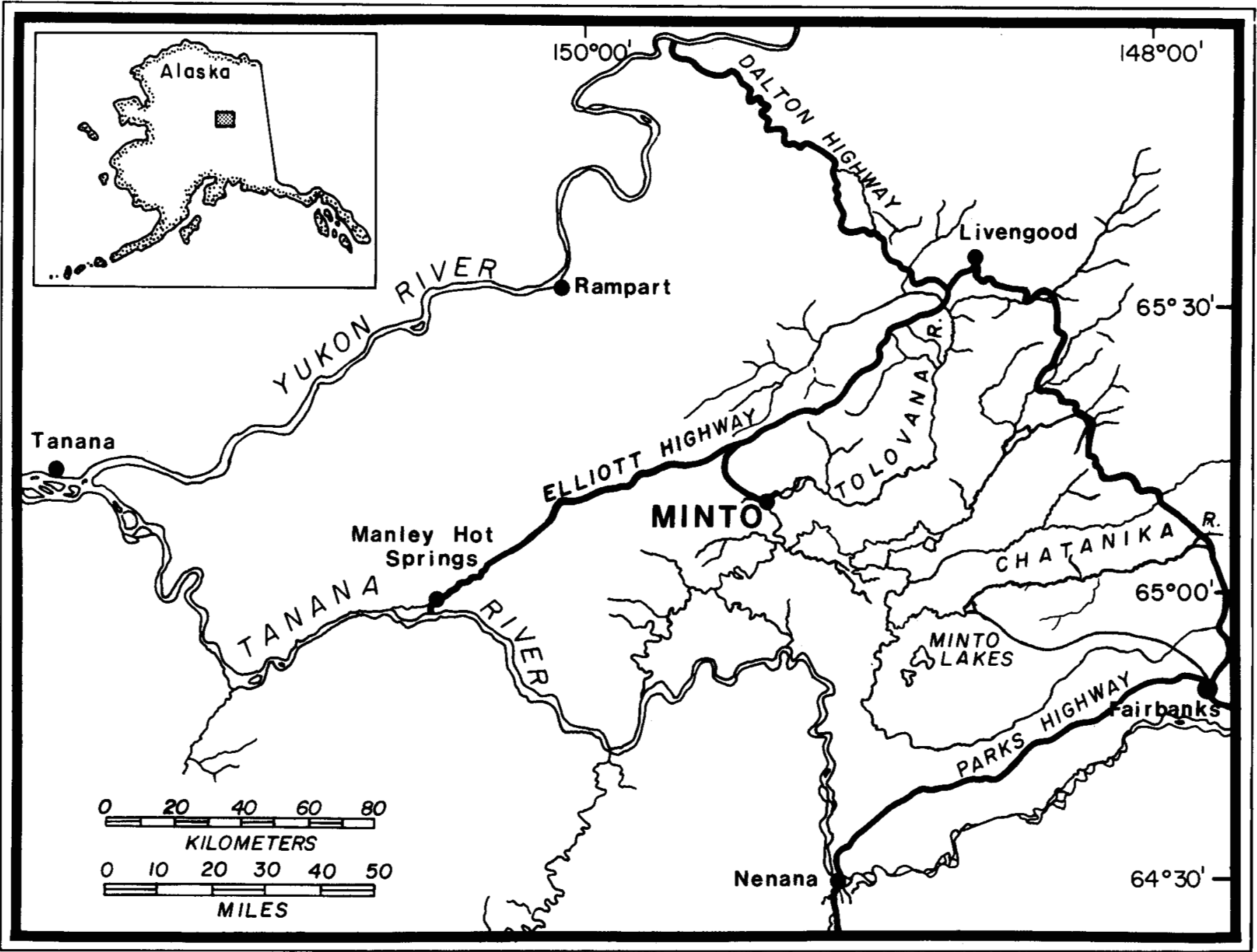

FIG. 1. Location of Minto, Alaska.

suggests that the subsistence and sport fisheries are not incompatible. It is, however, necessary to recognize the existence of, and activities associated with, low-profile subsistence fisheries to provide compatible yet different uses of the species.

\section{SUBSISTENCE FISHING IN MINTO FLATS}

Subsistence fishing in the Minto Flats area has a long history. The major settlements of the indigenous people of Minto Flats were situated at key fishing locales near Minto Lakes and along the Chatanika River during the late 19th and early 20th centuries (Fig. 2). Ten fish species other than salmon that seasonally inhabit the lakes and streams of Minto Flats have been harvested to varying degrees. In the 1980s, as in the past, virtually all fishing for freshwater fish by Minto residents occurred in these lakes and streams. Most fishing took place at four localities where major historic settlements were situated: Four-Cabin, Cache, Chatanika, and North Fork. These sites were significant because their geographic location allowed seasonal interception of migrating fish, par- ticularly whitefish, and because of the seasonal availability of other wildlife in relative proximity to the sites.

\section{Pike Fishing}

In the $1980 \mathrm{~s}$, as in earlier times, pike fishing usually occurred in late fall after freeze-up and in spring, but also during summer. It took place near the present village site called New Minto along the Tolovana River and at historically used localities in the eastern portion of Minto Flats (Fig. 2). The area $11 \mathrm{~km}$ above and below the present site of Minto was used historically for pike fishing. Cabins were built there between 1901 and 1930 when Old Minto, a semipermanent settlement, was located along the Tanana River. The other primary pike fishing areas were in the Minto Lakes area and along the Chatanika River above the mouth of Goldstream Creek. Both localities have been used historically when the major seasonal settlements of the Minto people were situated there. It was from these settlements that people relocated to the village of Old Minto on the Tanana River between 1917 and 1950. After 1950, people continued to use 


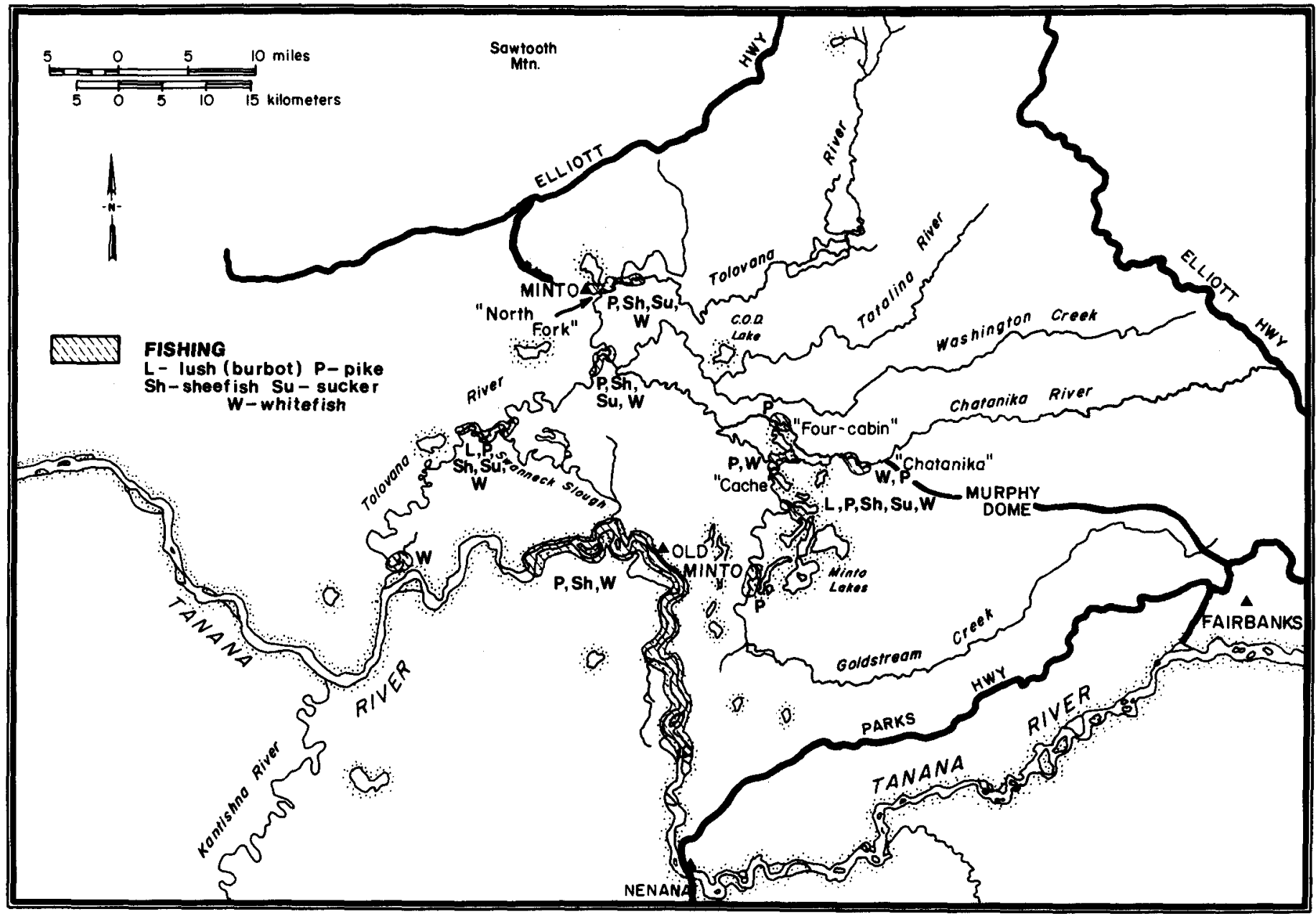

FIG. 2. Minto freshwater fishing areas, including pike, 1960-84.

the area for fall and spring camping for harvesting pike and other resources. In the 1980 s, Minto people fished and hunted in the area during certain seasons using the same camps.

Minto residents harvested pike for subsistence at several discrete times of the year using several methods. In the 1980s they fished for pike through the ice by "hooking" or "jigging," generally in October, November, and December. In addition, short gill nets were sometimes set under the ice before it became too thick. Pike were frozen whole if not used immediately. In April, May, and June individuals and families camped in the Minto Lakes area and set nets, generally $6.1-7.6 \mathrm{~m}$ in length, to harvest pike as well as whitefish. Dip nets were used also. The pike and whitefish were cut and dried at camp.

From June through September nets were set near the village to harvest several species of fish, including pike. Pike fishing using rod-and-reel gear usually took place in June after the high water receded following breakup and in late August when the water level generally dropped again. Other localities along the lower Tolovana River were used during midsummer and early fall for gill net fishing. For example, in early July, short gill nets were set for non-salmon species while families were at salmon fishing camps awaiting the run of salmon and in September when moose hunters sometimes set nets for catching sheefish and pike for food while moose hunting.
Finally, pike were caught incidentally in set nets and fishwheels used for salmon fishing along the Tanana River. The most productive pike fishing methods were hooking pike through the ice in October, November, and December and using gill nets during late spring and early summer.

A harvest survey conducted in the community in 1984 recorded the amount of fish and wildlife harvested by all Minto households $(\mathrm{N}=45)$ from July 1983 through June 1984 (Andrews, 1988). During the study year, $60 \%$ of Minto households harvested pike. The total village harvest was 3003 pike, which accounted for $7.56 \%$ of all fish and wildlife harvested by community residents during that time (Andrews, 1988). The per capita harvest of pike was $33.86 \mathrm{~kg}$. In contrast, this was more than four times the average annual use of fish in the United States $(7.71 \mathrm{~kg} /$ person) and about one-third of all meat, fish, and poultry used by the average American (115.65 kg/person) (U.S. Department of Commerce, 1984).

\section{SPORT FISHING FOR PIKE IN MINTO FLATS}

Since the 1960s, a sport fishery for pike has developed in the Minto Flats, which, as will be shown, has affected the biological resource and the preexisting subsistence fishery. This section describes development of these events followed 
by how the State of Alaska's management system has dealt with it.

The use of Minto Flats for recreational purposes by persons living outside the area began during the second half of this century. Recreational cabins in the Minto Lakes area were first constructed by sportsmen from Fairbanks in the late 1940s and early 1950s primarily for waterfowl hunting, but also for pike fishing and moose hunting (Shepherd and Matthews, 1985:39). Access was primarily by aircraft. In 1970, the new village site of Minto along the Tolovana River was connected by gravel road to the Elliott Highway and Fairbanks ( $209 \mathrm{~km}$ distant), enabling road access to the waterways of Minto Flats.

During that time, the Minto Flats sport pike fishery was considered one of the most productive in the state. It was primarily a summer fishery. Biological studies began in the mid-1960s and found Minto Flats pike to be of trophy size (Alt, 1969). Annual creel censuses also showed the importance of this sport fishery to Fairbanks sportsmen (Shepherd and Matthews, 1985:63). In the early 1970s biological studies and creel censuses continued, but subsequently were discontinued after 1973 (Shepherd and Matthews, 1985:64-65). Sport harvest estimates of northern pike have since been generated from a statewide mail survey. These estimates showed a gradual $50 \%$ reduction in the annual sport harvest of Minto Flats pike over the 6-year period from 1977 to 1982 (Shepherd and Matthews, 1985:66).

A significant change in access to the Minto Flats occurred in 1982 when a road was constructed from Murphy Dome northwest of Fairbanks to the Chatanika River. The road provided easy access to the Minto Flats area from Fairbanks (ca. $48 \mathrm{~km}$ ), especially during winter by snow machine (Shepherd and Matthews, 1985:39). The result of the road access was a large increase in sport fishing in the Minto Flats. A 1985 survey showed that the use of Minto Flats for sport fishing constituted 1040 user-days by respondents, second only to the use of the Flats for waterfowl hunting (1105 days). This survey primarily reflected the summer rod-and-reel fishery. By winter 1986-87, the increased use of the Murphy Dome Road extension to the Chatanika for winter ice fishing for pike had become critical, as described below.

\section{REGULATORY HISTORY}

The State of Alaska Board of Fisheries regulates the taking of fish in Alaskan waters, including pike fishing. Previous to 1961 , there were no state regulatory restrictions on subsistence pike fishing by local residents. Although the Minto Flats subsistence pike fishery has been an important part of the subsistence economy of the Minto people throughout the 20th century into the 1980s, in 1961 the Alaska Board of Fisheries closed the Chatanika River to subsistence fishing for northern pike and in 1980 closed Goldstream Creek to subsistence fishing. Both of these streams had been used customarily for pike fishing from seasonal camps situated along each stream. In spite of the regulations, subsistence pike fishing continued in these areas by Minto residents (Hinman, 1953; Olson, 1968; Alt, 1969; Cheney, 1972; Kepler, 1973; Andrews, 1988). Villagers generally were unaware of the regulatory closures until contacted in late 1986 by an officer from the Division of Fish and Wildlife Protection.
Since 1970 the sport fishery has been regulated by restricting harvests to a bag and possession limit of 2 pike 30 inches $(76 \mathrm{~cm})$ and longer and 10 pike less than 30 inches $(76 \mathrm{~cm})$. These regulations remained the same during the time when improved access was provided to Minto Flats, which enabled increased use, particularly of the eastern portion by boat and snow machine. By winter 1986-87, increased use of the Chatanika River for pike fishing had reached critical levels, causing concern to biologists. Although a sport harvest was provided for in regulation, the subsistence harvest of pike by Minto residents was not. The subsistence pike fishery was brought to the attention of fisheries managers. Villagers and managers alike were notified that subsistence pike fishing in the eastern Minto Flats was prohibited, yet sport fishing was allowed. In the 1960 s there was no subsistence law, so the state could prohibit subsistence fishing and yet allow sport fishing. Since 1978 the subsistence law has required that Minto's use of pike for subsistence be provided for, once it was determined that there was a harvestable surplus of the pike stock. In 1987 it was unclear whether the combined sport and subsistence harvest had exceeded the harvestable surplus of pike in the Minto area because of limited biological data on pike stocks. Taking a conservative management approach, the winter sport fishery was closed for conservation reasons. A petition from the Minto Village Council to the commissioner of the Alaska Department of Fish and Game to provide for customary subsistence fishing was received, discussed, and adopted in April 1987 by the Alaska Board of Fisheries. The summer and fall sport fisheries were kept open; however, the winter sport fishery was closed. Subsequently, biological research began in fall 1987 on the distribution and overwintering of pike in Minto Flats and to estimate the population. A permit requirement for subsistence pike fishing was established.

\section{COMPATIBILITY OF FISHERIES}

The Minto Flats subsistence pike fishery has been a customary and traditional fishery for the people of Minto for at least the past 100 years. Until recently, however, the fishery was not recognized in state regulation. The more recent sport fishery developed in an area with an existing subsistence fishery. An impact analysis of the interactions of the two fisheries was never done. Biological assessments of the status of Minto Flats pike stocks unfortunately were terminated just at the time when the sport fishery appears to have been expanding most rapidly.

In hindsight, probably the summer sport fishery was compatible with the preexisting subsistence net fishery: each occurred primarily at different times of the year and at different locations, and the level of take may have been within safe ranges for sustained yield. The winter sport fishery, however, boosted by the new Murphy Dome road extension, was less compatible: it overlapped with the subsistence fishery and the combined winter sport and subsistence harvests may have been at levels exceeding the harvestable surplus.

Biological studies aimed at determining stock composition, growth and mortality, and annual movements were initiated in late spring 1987 and continued through winter 1988 to help answer these questions (Holmes and Burkholder, 1988). These studies were designed also to sample the Minto Flats northern pike population to determine spawning areas and locations 
of overwintering concentrations by monitoring a sample of pike implanted with radio transmitters. Population studies using mark and recapture methods were conducted in 1988 and were planned to continue in 1989.

\section{CONCLUSIONS}

There are many examples of low-profile subsistence fisheries in arctic and subarctic Alaska. In addition to pike, there are subsistence fisheries that target blackfish, burbot, whitefish, sheefish, char, and trout, among others. In many areas of the state, these species are important in developing and expanding sport fisheries as well. In Alaska, fisheries are required to be conserved and managed consistent with the principle of sustained yield, and subsistence uses are to be afforded a preference among uses without jeopardizing fish stocks.

The Minto Flats pike fishery exemplifies the types of management and biological programs needed to achieve balanced fishing regulations. First, all uses of a fishery must be identified. A study of the subsistence pike fishery provided data on harvest levels, seasonality of harvest, gear, and geographic areas used. Similar data on the sport fishery revealed that the two fisheries were relatively discrete, except in winter. Generally, fishing areas did not overlap, nor did they occur concurrently. Regulations could be formulated that provided for both sport and subsistence uses during most seasons.

Data on the two fisheries pointed to the need for biological studies to identify the stocks being harvested and their growth, mortality, and recruitment. It was uncertain whether excessive harvests were occurring in areas important for spawning and of winter concentrations. Population estimates of the stock and other biological studies were deemed necessary to determine the status of the stock and its allowable harvest.

Standard management tools, such as protection of selected portions of the stocks, closed areas, closed seasons, and harvest and size limits, were all employed to provide for both conservation and continued uses of the fishery. The sport fishery was restricted to the summer and fall seasons to protect areas of concentration and portions of a stock. A harvest monitoring mechanism was instituted for subsistence fishermen, who were required to obtain a permit and report their harvest annually.

The Minto Flats pike fishery teaches an important lesson: an assessment should be made as to whether new or expanding sport fisheries are occurring in areas and on stocks that have preexisting subsistence uses. Knowledge of the nature and characteristics of both the subsistence and sport fisheries can make important contributions to the structure of regulations for all fishing activities. Equally important are biological data about the fish stocks, their composition, population status, spawning, and annual movements. All these data can then be analyzed to assess how the fishery should be managed given multiple demands and constitutional and statutory mandates. In this case, the state regulatory structure was capable of accommodating sport and subsistence uses consistent with the principle of sustained yield and a preference for subsistence uses.

\section{ACKNOWLEDGEMENTS}

I acknowledge the Alaska Department of Fish and Game for financial and logistical support. I thank the people of Minto for their hospitality, cooperation, and interest in the fish and wildlife harvest study from which these data were derived. I also acknowledge the cooperative efforts of the Minto Village Council, Tanana Chiefs Conference, Inc., and the Division of Sport Fish, Alaska Department of Fish and Game, Fairbanks, in proposing ways for regulating and managing the Minto Flats pike fisheries.

\section{REFERENCES}

ALASKA DEPARTMENT OF LABOR. 1987. Alaska population overview, 1985 estimates. Juneau: Alaska Department of Labor. $83 \mathrm{p}$.

ALLEN, H.T. 1887. Report of an expedition to the Copper, Tanana, and Koyukuk rivers, in the territory of Alaska, in the year 1885. Washington: Government Printing Office. $172 \mathrm{p}$.

ALT, K.T. 1969. Sheefish and pike investigations of the upper Yukon and Kuskokwim drainages with emphasis on Minto Flats drainage. D-J Annual Report of Progress. Juneau: Alaska Department of Fish and Game. 1969-70, Project F-9-1, 10:353-368.

ANDREWS, E.F. 1988. The harvest of fish and wildlife for subsistence by the residents of Minto, Alaska. Juneau: Division of Subsistence, Alaska Department of Fish and Game. Technical Paper No. 137. 334 p.

CHENEY, W.L. 1972. Life history investigations of northern pike in the Tanana River drainage. Federal Aid in Fish Restoration, Annual Report of Progress 1970-71. Juneau: Alaska Department of Fish and Game. Project F-9-3, 12:1-30.

HINMAN, R.A. 1953. A study of northern pike in Minto Lakes, Alaska. Unpubl. ms. Available at Rasmuson Library, University of Alaska, Fairbanks.

HOLMES, R.A., and BURKHOLDER, A. 1988. Movements and stock composition of northern pike in Minto Flats. Juneau: Division of Sport Fish, Alaska Department of Fish and Game. Fisheries Data Series No. 53. 34 p.

KEPLER, P. 1973. Population studies of pike and whitefish in Minto Flats complex with emphasis on the Chatanika River. Federal Aid in Fish Restoration, Annual Report of Progress, 1972-73. Juneau: Alaska Department of Fish and Game. Project F-9-6, 15:59-79.

MARCOTTE, J. 1986. Contemporary resource use patterns in Huslia, Alaska, 1983. Juneau: Division of Subsistence, Alaska Department of Fish and Game. Technical Paper No. 133. 70 p.

OLSON, W. 1968. Minto, Alaska: cultural and historical influences on group identity. M.A. thesis, University of Alaska, Fairbanks. 302 p.

OSGOOD, C. 1940. Ingalik material culture. Yale University Publications in Anthropology 22. New Haven: Yale University. $500 \mathrm{p}$.

SCHWATKA, F. 1893. A summer in Alaska. St. Louis: J.W. Henry. 418 p.

SHEPHERD. P.E.K., and MATTHEWS, M.P. 1985. Impacts of resource development and use on the Athabaskan people of Minto Flats, Alaska. Fairbanks: Tanana Chiefs Conference, Inc. 158 p.

U.S. DEPARTMENT OF COMMERCE. 1984. Statistical abstract of the United States 1984. 105th ed. Table No. 196, per capita consumption of major food commodities: 1960-1983. Washington, D.C.

WOLFE, R.J. 1979. Food production in a western Eskimo population. Ph.D. dissertation, Department of Anthropology, University of California, Los Angeles. $301 \mathrm{p}$.

and WALKER, R.J. 1987. Subsistence economies in Alaska: productivity, geography, and development impacts. Arctic Anthropology 24(2):56-81.

ZAGOSKIN, L.A. 1967. Lieutenant Zagoskin's travels in Russian America, 1842-44. Arctic Institute of North America, Anthropology of the North: Translations from Russian Sources, No. 7. Edited by Henry N. Michael. Toronto: University of Toronto Press. 358 p. 